\title{
Introduction
}

On 18 April 1972, some unusual guests arrived at Lohn, the Swiss government's luxurious country residence on the outskirts of Bern. A delegation of highranking representatives of the governments of Algeria, Cameroon, Kenya, Mali, Mauritania, and Zambia, headed by Moktar Ould Daddah, President of Mauritania and Chairman of the Assembly of Heads of State and Government of the Organization of African Unity (OAU), had flown in to discuss Switzerland's foreign policy in Africa. Specifically, the African diplomats wished to convince the Swiss government to take a stand against the white minority regimes in South Africa, Rhodesia, and the Portuguese colonies and to stop Swiss investment in these countries. During the reception at Lohn that preceded the official state dinner, the Swiss President, Nello Celio, expressed the Swiss people's sympathy for Africa and outlined the three principles that guided Switzerland's foreign policy in sub-Saharan Africa:

The first [principle] is that of non-interference in the affairs of another state; in our view, this principle is one of the pillars of the international legal order and, at the same time, a mandatory guideline for a country aspiring to a policy of neutrality. [...] [T] he second principle that guides us is our regard for the equality of all men and our condemnation of all forms of discrimination, be it political, racial, or religious, wherever it occurs. [...] There is a third principle that Switzerland has adhered to at all times. It is the principle of liberalism that secured the independence and liberty of its people. This also applies to the economic sphere; in accordance with this principle, the state cannot intervene at will in the economic sector. ${ }^{1}$

The OAU delegation's three-day visit to Bern was occasioned by fundamental differences over Switzerland's role in sub-Saharan Africa. In the late 196os, certain African nationalist movements and independent African governments started to criticise Switzerland's foreign policy concept, as sketched by

1 Address by Nello Celio, Swiss President, "Allocution prononcée par le Président de la Confédération, M. Nello Celio, à l'occasion du dîner offert en l'honneur de la délégation de l'OUA, le 18 avril 1972", no date, pp. 1-2, Swiss Federal Archives, Bern, Switzerland (SFA) E2001E-01\#1982/58\#440*. See also no author, "Programme pour la visite à Berne de la délégation de l'Organisation de l'Unité Africaine du 18 au 20 avril 1972", no date, ibid.

(C) SABINA WIDMER, 2021 | DOI:10.1163/9789004469617_002

This is an open access chapter distributed under the terms of the CC BY-NC-ND 4.0 licengnse. widmer - 9789004469617 
President Celio. By this time, the newly independent states of the Third World ${ }^{2}$ formed a majority in many international organisations and used this numerical advantage to demand a reorganisation of the global economic system. They also called for an end to the last bastions of white rule in the South of the African continent - the Portuguese colonies Angola and Mozambique, Apartheid South Africa which occupied Namibia, and the illegal settler regime in Rhodesia - and supported African movements fighting for national liberation. For Afro-Asian leaders, Bern's attempts to keep out of political debates about white minority rule and its refusal to consider cutting, or even reducing, its economic and financial ties with the white minority regimes in Southern Africa were incompatible with neutrality, as they amounted to taking a position on the racialised conflicts in this region. They refused to accept the Swiss government's strict differentiation between political principles and economic activities and were unimpressed by a verbal insistence on human rights that rarely went beyond abstract declarations. At the United Nations General Assembly (UNGA) and meetings of the OAU, they accused Swiss foreign policymakers of using neutrality as a smokescreen for economic interests and racism. The Bern visit was part of an extensive diplomatic offensive launched by the OAU in mid-1970 with trips to Washington, London, Paris, Bonn, and Rome aimed at convincing the Western bloc to take effective measures to end racial discrimination in Southern Africa. In a second step, the visiting programme was extended to the other member states of the North Atlantic Treaty Organization (NATO), neutral Sweden and Finland which were supportive of the liberation struggles in Southern Africa, and Switzerland and Japan, important trade partners of South Africa. Even though Switzerland was not the only target of criticism, this undermined its image in Third World states, which were important markets for the Swiss export industry. The credibility of Switzerland's neutrality was weakened not only by the country's political, economic, and ideological proximity to the Western bloc but also, and even more crucially, because it was part of the capitalist, industrialised North.

This book explores these disagreements over neutrality, economic interests, and human rights, which dominated Swiss foreign policymaking on sub-Saharan Africa in the late 196os and 1970s. They were shaped not only by

2 On the term "Third World" and its relation to the Cold War, see the discussion in Odd Arne Westad, The Global Cold War: Third World Interventions and the Making of Our Times, Cambridge: Cambridge University Press, 2005, pp. 2-3. Westad underlined that the term "indicates colonial and postcolonial processes of marginalization (and the struggle against these processes.)" This book follows his pragmatic definition of the Third World as "the former colonial or semicolonial countries in Africa, Asia, and Latin America that were subject to European (or rather pan-European, including American and Russian) economic or political domination." Ibid., p. 3 . 
the intensification of the North-South conflict that reached its apex in the mid-197os but also by the ramifications of the global Cold War. ${ }^{3}$ In this crucial period in international relations, variously called Détente, the "long 197os"4 or the "global 196os and 1970s", 5 bilateral superpower relations relaxed. At the same time, the intersections of decolonisation and the Cold War had their most striking and violent implications on the African continent, as newly independent African actors sought their place in a bilateral world and the United States of America (US) and the Union of Soviet Socialist Republics (USSR) attempted to control them. When local conflicts broke out, the superpowers and their allies provided the belligerents with training, supplies, and even troops. This exacerbated and frequently prolonged conflicts, with disastrous results for local populations. These interventions in local wars increased bilateral tension between the US and the Soviet Union. ${ }^{6}$ In turn, the collapse of Détente in the late 1970 s weakened the Third World's challenge to the global economic system and its demands for the end of racial discrimination in Southern Africa, ${ }^{7}$ calls that had been taken up by the global ' 1968 ' non-state protest movement. ${ }^{8}$

By analysing how Switzerland, a small, European, neutral state that had never been a colonial power, responded to the challenges arising from the intersection of Cold War dynamics and decolonisation in sub-Saharan Africa during this period of profound political, economic, and social change, this book contributes to the international history of the late 196os and 1970s. It focuses on Switzerland's foreign policy in Angola, Mozambique, Ethiopia, and Somalia. These four African states were not chosen for the importance of their bilateral relations with Switzerland, as political and economic exchanges were limited. Rather, the choice is explained by the special role of these states at the centre of global East-West and North-South confrontations in this period.

3 Westad coined this expression in his seminal study, The Global Cold War.

4 Poul Villaume, Rasmus Mariager, Helle Porsdam (eds.), The 'Long 197os'. Human Rights, EastWest Détente and Transnational Relations, Farnham: Ashgate, 2016.

5 This is the title of a new Routledge series in Cold War History: https://www.routledge.com/ The-Routledge-Global-196os-and-197os-Series/book-series/GLOBALSIXTIES (13 January 2021). See also Niall Ferguson et al., The Shock of the Global. The 197os in Perspective, Cambridge MA: The Belknap Press of Harvard University Press, 2010.

6 For an overview of these dynamics, see Jeffrey James Byrne, "Africa's Cold War", in Robert J. McMahon (ed.), The Cold War in the Third World, New York: Oxford University Press, 2013, pp. 101-123.

7 See notably Giuliano Garavini, After Empires. European Integration, Decolonization \& the Challenge from the Global South 1957-1986, Oxford: Oxford University Press, 2012; Mark Mazower, Governing the World. The History of an Idea, London: Allen Lane, 2012.

8 See notably Konrad J. Kuhn, "Liberation Struggle and Humanitarian Aid: International Solidarity Movements and the 'Third World' in the 196os", in Samantha Christiansen, Zachary A. Scarlett (eds.), The Third World in the Global rg6os, New York: Berghahn Books, 2013, pp. 69-85. 
Regime changes in Somalia (1969), Ethiopia (1974), Mozambique (1975), and Angola (1975-1976) led to a shift in superpower alliances on the African continent. The new governments of these four states were more overtly inspired by Marxism than the 'African Socialism' adopted by other governments in the late 195os and early 196os, and they concluded cooperation treaties with the USSR. These regime changes were accompanied by anti-Western rhetoric, the nationalisation of foreign property, and moves towards a more state-controlled economy. In addition, in all four countries, armed conflicts caused by internal events - the wars in Angola and Mozambique between the Portuguese colonial power and nationalists fighting for independence (1961-1974 and 1964-1974), in Angola between different liberation movements (1975-1976), and in the Ogaden region between neighbouring Ethiopia and Somalia (1977-1978) - were shaped and influenced by the various forms of support that the different belligerents received from both sides of the Cold War and by the North-South divide.

Based on extensive multi-archival research, this book demonstrates that between 1967 and 1979, the Swiss government's policy in sub-Saharan Africa was determined by the need to improve its international image and the credibility of its neutrality. Through the pragmatic use of diplomatic goodwill gestures and humanitarian and development aid, the Swiss government succeeded in maintaining its political and economic presence in Southern Africa and the Horn throughout armed conflicts, decolonisation, and regime changes. Moreover, it successfully fended off Afro-Asian criticism of its policy of neutrality while preserving close relations with the Western bloc. Moving beyond the Swiss case, the book exposes the limits of neutrality as a foreign policy guideline in North-South relations, reveals the growing marge de manoeuvre of small states in the international system during Détente, and highlights the role of non-state actors in the making of foreign policy.

Neutrality is at the core of this story. In its original form, neutrality began to emerge in seventeenth century Europe and only applied in times of war. It is enshrined in international law and was codified in the Fifth Hague Convention of 1907. The convention guarantees the inviolability of a neutral power's territory and requires it to prevent belligerents from moving troops or supplies across its land. If a neutral state decides to limit or prohibit the export of any goods that can be used in war, these restrictions must be impartially applied to all belligerents. ${ }^{9}$ During the Cold War, the law of neutrality did not apply, as

9 For history of the law of neutrality, see notably Stephen C. Neff, The Rights and Duties of Neutrals: A General History, Manchester: Manchester University Press, 20oo, here particularly pp. 129-130. 
this conflict was, from a legal perspective, not a war. However, neutrality also has a political dimension. This has no foundation in law but includes "all measures intended to strengthen and protect the law of neutrality". ${ }^{10}$ For a permanently neutral state like Switzerland, whose status was recognised by the Great Powers after the Congress of Vienna in 1815, a credible neutrality thus implied avoiding any policy that might undermine its ability to remain neutral in any future conflict, notably by not entering into peacetime alliances.

At the end of the Second World War, neutrality was discredited. It was either seen as ineffective, as the neutral Netherlands had been occupied by Nazi Germany and had subsequently abandoned neutrality, or morally reprehensible, as Switzerland and Sweden had collaborated with the axis powers. Swiss and Swedish foreign policymakers were therefore much concerned with recovering the credibility and respectability of their neutrality, the two main criteria, according to political scientist Harto Hakovirta, for the assessment of a policy of neutrality. ${ }^{11}$ Their efforts to convince other states of the usefulness of a neutral stance, notably by offering mediation or pursuing a humanitarian agenda, were even more important in the context of growing East-West polarisation. By the mid-1950s, both superpowers, which had been highly critical of neutrality at the end of the Second World War, had recognised its potential benefits and accepted the status of the five European neutrals: Switzerland, Sweden, Austria, Ireland, and Finland..$^{2}$

Jürg Martin Gabriel, The American Conception of Neutrality After 1941, Basingstoke: Palgrave Macmillan, 2002 (Updated and Revised Edition), p. 12.

11 Harto Hakovirta, East-West Conflict and European Neutrality, Oxford: Clarendon Press, 1988, pp. 26-29. On Switzerland's foreign policy during the Second World War, consult notably Hans Ulrich Jost, Politik und Wirtschaft im Krieg. Die Schweiz 1938-1948, Zürich: Chronos, 1998; Independent Commission of Experts Switzerland - Second World War (ed.), Switzerland, National Socialism and the Second World War. Final Report, Zurich: Pendo, 2002; Marc Perrenoud, "Léconomie suisse et la neutralité à géometrie variable", Matériaux pour l'histoire de notre temps 93 (2009), pp. 77-86; Neville Wylie, "Switzerland: a neutral of distinction?" In Neville Wylie (ed.), European Neutrals and Non-Belligerents during the Second World War, Cambridge: Cambridge University Press, 2002, pp. 331-354. For a brief overview, consult Marco Wyss, Jussi M. Hanhimäki, Sandra Bott, Janick Marina Schaufelbuehl, "Introduction. A Tightrope Walk - Neutrality and Neutralism in the Global Cold War", in Sandra Bott, Jussi M. Hanhimäki, Janick Marina Schaufelbuehl, Marco Wyss (eds.), Neutrality and Neutralism in the Global Cold War. Between or Within the Blocs? London: Routledge, 2016, pp. 1-14. On the attitude of the US, see notably Michael T. Ruddy, "European Integration, the Neutrals, and U.S. Security Interests: From the Marshall Plan to the Rome Treaties", in Michael Gehler, Rolf Steininger, (eds.), Die Neutralen und die europäische Integration 1945-1995, Wien: Böhlau, 2000, pp. 13-28; Gabriel, The American Conception of Neutrality After 1947; on that of the Soviet Union, Vladislav M. Zubok, "The Soviet Attitude towards the European Neutrals during the Cold War", in Gehler, Stein- 
Towards the end of the Second World War and during the early years of the Cold War, Switzerland's political leaders started to formulate a very restrictive foreign policy doctrine. It was based on a narrow, idealised conception of neutrality that began to take on an almost mythical importance and venerated Switzerland as a 'special case' in Europe and the world. In order to overcome Switzerland's international isolation and improve the image of its neutrality policy, this leading principle was complemented by the principles of solidarity and universality. While the first demanded commitment to good offices and humanitarian aid, the second called for the diplomatic recognition of all states, no matter the political couleur of their regimes. The willingness to offer good offices and mediation in international conflicts would, in the early 196os, be subsumed under the additional principle of availability. ${ }^{13}$

Although Switzerland did not formally join one of the Cold War blocs, several scholars have pointed out that its neutrality was compromised by the clear Western orientation of its foreign policy. The Swiss government and the majority of its population were strongly anti-Communist and had much closer economic, political, and military links to the US and Western Europe than to the USSR and the Eastern bloc. ${ }^{14}$ Neutrality was thus a flexible principle that was

inger, Die Neutralen und die europäische Integration, pp. 29-43; Wolfgang Mueller, "The US and Permanent Neutrality in the Cold War", Journal of Cold War Studies 18:4 (2016), pp. 148-179; Peter Ruggenthaler, The Concept of Neutrality in Stalin's Foreign Policy, Latham: Lexington Books, 2015 .

13 See notably Thomas Fischer, Daniel Möckli, "The Limits of Compensation: Swiss Neutrality Policy in the Cold War", Journal of Cold War Studies 18:4 (2016), pp. 12-35; Daniel Möckli, Neutralität, Solidarität, Sonderfall. Die Konzeptionierung der schweizerischen Aussenpolitik der Nachkriegszeit, 1943-1947, Zürich: Forschungsstelle für Sicherheitspolitik und Konfliktanalyse ETH, 2000; Daniel Trachsler, Neutral zwischen Ost und West? Infragestellung und Konsolidierung der schweizerischen Neutralitätspolitik durch den Beginn des Kalten Krieges, 1947-1952, Zürich: Forschungsstelle für Sicherheitspolitik und Konfliktanalyse EтH, 2002; Daniel Trachsler, Bundesrat Max Petitpierre. Schweizerische Aussenpolitik im Kalten Krieg 1945-1961, Zurich, NZZ, 2011.

14 On Swiss anti-Communism, consult Daniel Alexander Neval, 'Mit Atombomben bis nach Moskau'. Gegenseitige Wahrnehmung der Schweiz und des Ostblocks im Kalten Krieg 19451968, Zürich: Chronos, 2003; Luc van Dongen, "La Suisse dans les rets de l'anticommunisme transnational durant la Guerre froide: réflexions et jalons", in Sandra Bott, Janick Marina Schaufelbuehl, Sacha Zala (eds.), Itinera. Die internationale Schweiz in der Zeit des Kalten Krieges/Relations internationales de la Suisse durant la Guerre froide, Basel: Schwabe, 2011, pp. 17-30; several articles in Luc van Dongen, Stéphanie Roulin, Giles Scott-Smith (eds.), Transnational Anti-Communism and the Cold War. Agents, Activities, and Networks, Basingstoke: Palgrave Macmillan, 2014; Hadrien Buclin, "Swiss Intellectuals and the Cold War: Anti-Communist Policies in a Neutral Country", Journal of Cold War Studies 19:4 (2017), pp. 137-167. On Swiss pro-Western neutrality, which was nevertheless accepted by the USSR, see notably Hans Ulrich Jost, "Switzerland's Atlantic Perspectives", in Marko 
applied in a selective manner. The somewhat artificial differentiation between 'technical' and 'political' international organisations-adhesion to the former being compatible with neutrality and to the latter not-is only one example of how Bern managed to steer its foreign policy according to its national, mainly economic, interests. The ambiguous relationship between neutrality and economic interests has also been criticised. Historian Hans Ulrich Jost pointedly argued that Switzerland's "idealistic principle of neutrality, with its humanitarian connotation" has served as a shield to hide the sword of foreign trade, which "is wielded without moral reticence in the markets and business affairs of the world". ${ }^{15}$ This was exactly the accusation made by the African visitors to Bern in 1972.

Research on neutrality during the Cold War has mainly focused on the European theatres of the East-West conflict. By concentrating on the conflicts surrounding neutrality in sub-Saharan Africa and thereby extending the analysis to the global South, this book shows that neutrality was an even more malleable foreign policy concept in the Third World, where the danger of a neutral state being directly involved in armed conflict was much lower than in Europe. As a consequence of the decolonisation of most sub-Saharan African states in the late 1950s and early 196os, the concept of neutrality — developed in a European context - needed to prove its credibility and respectability to a new set of actors. During the tensions and wars of the late 196os and 1970s, where the lines of the East-West and North-South conflicts intersected, it became difficult to maintain a neutrality policy that was credible and respectable in the eyes of both unofficial Western allies and the rising Third World. Although this book does not adopt a truly comparative approach, it contrasts Switzerland's foreign policy in sub-Saharan Africa to that of other European neutrals, thereby contributing to a better understanding of the meaning of neutrality in the Third World during the Cold War.

Milivojevic, Pierre Maurer (eds.), Swiss Neutrality and Security: Armed Forces, National Defence and Foreign Policy, New York: Berg, 199o, pp. 110-121; Janick Marina Schaufelbuehl, Mario König (eds.) Traverse. Schweiz-USA im kalten Krieg/Suisse-USA dans la guerre froide, 16:2 (2009); and with regard to military and security policy, Mauro Mantovani, Schweizerische Sicherheitspolitik im Kalten Krieg (1947-1963). Zwischen angelsächsischem Containment und Neutralitäts-Doktrin, Zürich: Orell Füssli, 1999; André Schaller, Neutralität im West-Ost Handel: Das Hotz-Linder Agreement vom 23. Juli 1951, Bern: Haupt, 1987; Marco Wyss, "Neutrality in the Early Cold War: Swiss Arms Imports and Neutrality", Cold War History 12:1 (2012), pp. 25-49; Marco Wyss, Arms Transfers, Neutrality and Britain's Role in the Cold War: Anglo-Swiss Relations 1945-1958, Leiden: Brill, 2013.

15 Jost, "Switzerland's Atlantic Perspectives", p. 113. See also Hans Ulrich Jost, "Origines, interprétations et usages de la 'neutralité helvétique', Matériaux pour l'histoire de notre temps 93 (2009), pp. $5^{-12 .}$ 
Switzerland and Sweden, and, to a lesser extent, Austria, whose neutral status (declared in 1955) was based on the Swiss model, ${ }^{16}$ closely observed each other's policy decisions; as has been shown with regard to the recognition in the 1970s of the Communist halves of the divided states of Korea and Vietnam. ${ }^{17}$ This tension between cooperation and competition can also be observed in sub-Saharan Africa. Sweden was Switzerland's main competitor in this region, as the Austrian government was less exposed to criticism of its African policy and less interested in close relations with African states. The two other European neutrals, Finland and Ireland, were no reference for Swiss foreign policymaking in sub-Saharan Africa. ${ }^{18}$ Sweden was a de facto neutral state, whose conception of neutrality came closest to that of Switzerland. ${ }^{19}$ Yet, there were significant differences between the two states' foreign policy approaches, particularly when it came to relations with the Third World. Unlike Switzerland, Sweden joined the United Nations (UN) in 1946. Its active foreign policy, which emerged in the late 1950s and early 1960s, included taking a more independent stance from the superpower blocs and an outspoken position in international

16 Austrian neutrality is notably analysed by Günter Bischof, Austria in the First Cold War, 1945-1955. The Leverage of the Weak, Basingstoke: Palgrave Macmillan, 1999; Michael Gehler, "From Non-alignment to Neutrality: Austria's Transformation during the First East-West Détente, 1953-1958", Journal of Cold War Studies 7:4 (2005), pp. 104-136; Wolfgang Mueller, A Good Example of Peaceful Coexistence? The Soviet Union, Austria, and Neutrality, 1955-1991, Wien: Verlag der Österreichischen Akademie der Wissenschaften, 2011; Erwin A. Schmidl, "Lukewarm Neutrality in a Cold War? The Case of Austria",Journal of Cold War Studies 18:4 (2016), pp. 36-50.

Janick Marina Schaufelbuehl, Marco Wyss, Sandra Bott, "Choosing Sides in the Global Cold War: Switzerland, Neutrality, and the Divided States of Korea and Vietnam", The International History Review 37:5 (2015), pp. 1014-1036.

18 On Finnish neutrality, see Martti Häikiö, "Finland's Neutrality 1944-1994", in Gehler, Steininger, Die Neutralen und die europäische Integration, pp. 199-217; Kimmo Rentola, "From Half-Adversary to Half-Ally: Finland in Soviet Policy, 1953-1958", Cold War History 1:1 (2000), pp. 75-102. For a comparative analysis of European neutrality, see Hakovirta, East-West Conflict and European Neutrality; Efraim Karsh, Neutrality and Small States, London: Routledge, 1988.

19 For studies of Swedish neutrality in English, see, for example, Juhana Aunesluoma, Britain, Sweden and the Cold War, 1945-54. Understanding Neutrality, Basingstoke: Palgrave Macmillan, 2003; Robert Dalsjö, "The Hidden Rationality of Sweden's Policy of Neutrality during the Cold War", Cold War History 14:2 (2014), pp. 175-194; Birgit Karlsson, "Neutrality and Economy: The Redefining of Swedish Neutrality, 1946-52", Journal of Peace Research 32:1 (1995), pp. 37-48; Mikael af Malmborg, Neutrality and State-Building in Sweden, Basingstoke: Palgrave Macmillan, 20o1; Simon Moores, "'Neutral on our Side': US Policy towards Sweden during the Eisenhower Administration", Cold War History 2:3 (2002), pp. 29-62. 
affairs, an emphasis on human rights and development issues, and generally paying closer attention to the Third World. ${ }^{20}$

Building on Tor Sellström's meticulous reconstruction of Swedish diplomatic and humanitarian support for national liberation in Southern Africa, ${ }^{21}$ this book shows that there were different, competing models of a neutral foreign policy on the African continent. Switzerland's image problem on the African continent was compounded by the fact that African actors frequently compared its foreign policy to that of Sweden. The Swiss conception of neutrality-which insisted on the principle of non-interference in the internal affairs of other states and the separation of political and economic issueswas poorly adapted to a context where conflicts focused on the end of white minority rule and the reorganisation of global economic relations. Yet, while Switzerland's foreign policy in sub-Saharan Africa was criticised by Afro-Asian governments, Sweden's outspoken position created tension with the leaders of the Western bloc. One side's 'good neutrals' were the other's 'bad neutrals'. Considering these different interpretations of the flexible principle of neutrality, it follows that it was of limited use as a foreign policy guideline in NorthSouth relations.

The Swiss case is not only instructive to the study of neutrality but also to the analysis of the role and influence of small states in the international system during the global Cold War. In his classic comparative analysis of European small open economies, political scientist Peter Katzenstein briefly turned to the Third World policies of Sweden, Norway, Denmark, the Netherlands, Belgium,

20 For a historiographical overview on Swedish foreign policy during the Cold War, see Ulf Bjereld, Ann-Marie Ekengren, "Cold War Historiography in Sweden", in Thorsten B. Olesen (ed.), The Cold War - and the Nordic Countries: Historiography at Crossroads, Odense: University Press of Southern Denmark, 2004, pp. 143-175. Swedish Third World policy is analysed by Nikolas Glover, "Neutrality Unbound. Sweden, Foreign Aid and the Rise of the Non-Aligned Third World", in Bott et al., Neutrality and Neutralism in the Global Cold War, pp. 161-177. See also Magnus Jerneck, "Sitting on the Balcony: American Responses, Strategic Dilemmas, and Swedish Criticism of the Vietnam War", Diplomacy \& Statecraft 24:3, pp. 404-426; Aryo Makko, "Sweden, Europe, and the Cold War: A Reappraisal", Journal of Cold War Studies 14:2 (2012), pp. 68-97. Comparative studies of Switzerland's and Sweden's neutrality policies during the Cold War include Mikael Nilsson, Marco Wyss, "The Armed Neutrality Paradox: Sweden and Switzerland in US Cold War Armaments Policy", Journal of Contemporary History 51:2 (2016), pp. 335-363; John F. L. Ross, Neutrality and International Sanctions. Sweden, Switzerland and Collective Security, New York: Praeger, 1989. 
Austria, and Switzerland. He argued that these small European states, which relied on the smooth functioning of the international economic and political order, tended to be more accommodative of Third World states' demands than larger Western powers. Nevertheless, he also showed that in the late 196os and 1970s, there were two fundamentally different approaches to North-South relations among small states. These were exemplified by Sweden and Switzerland. While the first backed many Third World demands, tied Swedish foreign investment to a code of good conduct, and granted generous public aid, the latter opposed the preferential treatment of imports from developing countries. Switzerland was committed to the defence of market liberalism, even though its government was careful to adopt a discreet position so as not to offend Third World representatives. Its public aid commitment was modest, amounting to $0.19 \%$ of Switzerland's gross national product, considerably lower than the Organisation for Economic Co-operation and Development (OECD) average of $0.31 \%$ and the organisation's target of $0.7 \%$, which Sweden exceeded. ${ }^{22}$ Although Katzenstein's argument was made in very general terms, the analytical category of the small state, which in his study included three neutrals and four NATO members, is a useful reminder that geopolitical alliances—or the absence of such alliances - are not sufficient to explain foreign policy choices.

What these states had in common was their limited political and military clout on the international scene. This left them more exposed to the multiple and interconnected political, economic, military, and social challenges of the period and restricted their leeway to tackle them. These challenges were manifold: armed conflicts in the Third World, most famously in Vietnam; superpower Détente; growing distance in transatlantic relations; ${ }^{23}$ economic crises and the collapse of the Bretton Woods international monetary system; the rise of political and social protest movements; ${ }^{24}$ and the North-South conflict that culminated in the 1973 'Oil Shock' and the Third World political movement's demands for a New International Economic Order (N IEO) in $1974 .{ }^{25}$ The

22 Peter Katzenstein, Small States in World Markets. Industrial Policy in Europe, Ithaca: Cornell University Press, 1985, pp. 46, 121-122.

23 Jussi M. Hanhimäki, The Rise and Fall of Détente. American Foreign Policy and the Transformation of the Cold War, Washington, DC: Potomac Books, 2013; Poul Villaume, Odd Arne Westad (eds.), Perforating the Iron Curtain. European Détente, Transatlantic Relations, and the Cold War, 1965-1985, Copenhagen: Museum Tusculanum Press, 2010.

24 See, for example, Martin Klimke, Joachim Scharloth (eds.), 1968 in Europe. A History of Protest and Activism, New York: Palgrave Macmillan, 2008; Jeremy Suri, Power and Protest. Global Revolution and the Rise of Détente, Cambridge, MA: Harvard University Press, 2005. See notably Christopher R. W. Dietrich, Oil Revolution. Anticolonial Elites, Sovereign Rights, and the Economic Culture of Decolonization, Cambridge: Cambridge University Press, 2017; Garavini, After Empires. 
increasingly divergent opinions and strategies of the US, on the one hand, and its Western European allies, on the other, of how to confront these issues are a recurring theme in the scholarship on the 'global 196os and 197os'. Building on this, this study testifies to the increased marge de manoeuvre during Détente for small Western European states to lead foreign policy independently of superpower influence. As the image of the US suffered due to the retreat from Vietnam and the Watergate scandal, Swiss foreign policymakers grew disillusioned with Washington's policy on Africa in the mid-1970s. This book shows that Switzerland's foreign policy in sub-Saharan Africa owed more to Western European governments, in terms of both influence and coordination, than to the US. In addition to neutral Sweden and Austria, it stresses the importance of the European Economic Community (EEC), as a collective political actor, to Switzerland's foreign policy in sub-Saharan Africa. Thus, this study also provides insights into the history of European integration and European foreign policymaking during the Cold War. ${ }^{26}$

It would be misleading to underestimate the influence of small Western European states in international relations. The mere fact that the oAU included them in its delegation's itinerary proves that they were indeed actors to be reckoned with. This was particularly true for Switzerland, whose economic and financial interests in sub-Saharan Africa, and especially in South Africa, were considerable. Its relations with the Apartheid regime were particularly important to Swiss capital exports and imports of South African gold. Historian Sandra Bott notably showed that, between the 196os and the late 1980s, up to $80 \%$ of South Africa's gold production was commercialised by Swiss banks, which strengthened the international position of the Swiss financial centre. ${ }^{27}$ Thanks to Switzerland's economic and financial strength, some authors have argued that, in these fields, the country was, at the least, a middle power. They claim that its political and economic leaders employed what historian Sébastien Guex called a 'rhetoric of smallness' to discreetly protect and further their interests. ${ }^{28}$ This book shows that Switzerland's close economic relations

26 On the foreign policy efforts of the European Economic Community (EEC), see notably Lorenzo Ferrari, Sometimes Speaking with a Single Voice. The European Community as an International Actor, 1969-1979, Bruxelles: P.I.E. Peter Lang, 2016; Maria Găinar, Aux origines de la diplomatie européenne. Les neuf et la coopération politique européenne de 1973 à 1989, Bruxelles: P.I.E. Peter Lang, 2012; Garavini, After Empires; Daniel Möckli, European Foreign Policy during the Cold War. Heath, Brandt, Pompidou and the Dream of Political Unity, London: I.B. Tauris, 2009.

Sandra Bott, La Suisse et l'Afrique du Sud. Marché de l'or, finance et commerce durant l'apartheid, Zurich: Chronos, 2013, p. 377.

28 Sébastien Guex, "Introduction. De la Suisse comme petit État faible: jalons pour sortir d'une image en trompe-l'oeil", in Sébastien Guex (ed.), La Suisse et les Grandes puissances. 
with South Africa explain why foreign policymakers were less critical of white minority rule than those in other small Western European states.

Many traditional works in diplomatic history limit their analysis to the actions of governments and foreign ministries. This study goes further. It looks at the various state and non-state actors that participated in the formation of Switzerland's foreign policy and analyses their interactions with each other, but also with African governments, nationalist movements, and regional and international organisations such as the OAU and the UN. Particular attention is paid to the influence of Western governments on Swiss decision-making and to the interplay of domestic and foreign policy. While the domestic context always limits a government's freedom of action in matters of foreign policy, this is particularly marked in a direct democracy like Switzerland, where citizens can, through a popular vote, pronounce themselves on certain foreign policy issues. The rejection by a majority of voters of a loan of 200 million Swiss francs (CHF) to the International Development Association (IDA) in mid-1976 and of Switzerland's membership of the UN in March 1986 are two cases in point. The focus on a wide range of state and non-state actors and different levels of analysis is particularly instructive, as proven by Rui Lopes' similarly designed study of West German - Portuguese relations during the late independence wars in Portuguese Africa. ${ }^{29}$

The sub-Saharan African context presented a few particularities. Most Swiss individuals, organisations, and government services participating in foreign policymaking had only limited knowledge of this region. As a result, their positions were almost always coloured by some form of racial prejudice. In addition, developments in Angola, Mozambique, Ethiopia, and Somalia rarely drew high-level attention in Bern. Most policy decisions were made at the administrative level and were frequently influenced by individual actors and interests. The Swiss government's information deficit was compounded by the fact that, with the exception of Ethiopia, the Swiss government had no resident ambassador in the four states selected for this study. In addition, the diplomatic personnel that served in Africa was far removed from the ambassadors

1914-1945. Relations économiques avec les États-Unis, la Grande-Bretagne, l'Allemagne et la France/Switzerland and the Great Powers. 1914-1945. Economic Relations with the United States, Great Britain, Germany and France, Genève: Librairie Droz, 1999, pp. 7-29. See also Antoine Fleury, "La Suisse: petite ou moyenne puissance?" in Jean-Claude Allain (ed.), La moyenne puissance au XXème siècle: recherche d'une définition, Paris: FEDN-IHCC, 1989, pp. 217-230.

29 Rui Lopes, West Germany and the Portuguese Military Dictatorship, 1968-1974. Between Cold War and Colonialism, Basingstoke: Palgrave Macmillan, 2014 
appointed to the prestigious posts at the centres of power-in particular the US, the United Kingdom (UK), France, and the Federal Republic of Germany (FRG). ${ }^{30}$ These factors contributed to increasing the opportunities for nonstate actors to influence the government's foreign policy.

Although state actors certainly played a central role in the making of Switzerland's foreign policy in sub-Saharan Africa, different sets of non-state actorsbusiness leaders and firms, missionaries and religious organisations, Third World solidarity groups, and the International Committee of the Red Cross (ICRC) - contributed in various ways to determine the government's position in specific policy fields. Leaders of Swiss companies and economic associations wanted to tap into new African markets and lobbied their government not to give in to Third World pressure to restrict trade with and investments in Southern Africa. Swiss missionaries played a valued role in the implementation of the Swiss government's development policy on the African continent; in the period under consideration, they and their families formed almost half of all Swiss citizens living in the Portuguese colonies and the Horn of Africa. They were in close contact with African populations and had, in some cases, direct links to present and future political leaders. Thus, some missionaries acted as a bridge not only between African populations and Swiss religious circles but also between African elites and the Swiss government.

Afro-Asian criticism of the Swiss government and Swiss business elites' close relations with the white minority regimes in Southern Africa was taken up by an important and heterogeneous protest movement in Switzerland that developed out of the 1968 student movement and religious circles. ${ }^{31}$ As part of a transnational movement that criticised unequal North-South relations, Swiss students, peace activists, left-wing groups, and also a number of churches, missionary organisations, social democratic politicians, and academics demanded that the Federal Council take a firm stand against racial

30 See Florian Keller, Botschafterporträts. Schweizer Botschafter in den "Zentren der Macht" zwischen 1945 und 1975, Zürich: Chronos, 2017.

$31 \quad$ See notably René Holenstein, Was kümmert uns die Dritte Welt. Zur Geschichte der internationalen Solidarität in der Schweiz, Zürich: Chronos, 1998; Monica Kalt, Tiersmondismus in der Schweiz der 196oer und 197oer Jahre. Von der Barmherzigkeit zur Solidarität, Bern: Peter Lang, 2010; Konrad J. Kuhn, Entwicklungspolitische Solidarität: die Dritte-Welt-Bewegung in der Schweiz zwischen Kritik und Politik 1975-1992, Zürich: Chronos, 2011; Nuno Pereira, Anti-impérialisme et nouvelle gauche radicale dans la Suisse des années 1968, unpublished $\mathrm{PhD}$ thesis, University of Lausanne, 2015; and the contributions in Janick Marina Schaufelbuehl (ed.), 1968-1978. Ein bewegtes Jahrzehnt in der Schweiz, Zürich: Chronos, 2009. On the 1968 movement in general, see Damir Skenderovic, Christina Späti, Die 1968er-Jahre in der Schweiz. Aufbruch in Politik und Kultur, Baden: Hier + jetzt, 2012. 
discrimination, prevent Swiss firms from participating in exploitative practices in the Third World, and make a positive contribution to the development of African states. Thus, the stance of this solidarity movement was in direct opposition to that of many Swiss business leaders. The ICRC organised important relief missions during the Angolan and the Ogaden wars, which received financial and logistical support from the Swiss government. As a result of the high level of mobilisation within Swiss society, Bern's policy in sub-Saharan Africa was closely scrutinised. This study shows that, while economic interests had, on the whole, a very strong influence on Swiss foreign policymakers, the demands of the Third World solidarity movement did have an effect, too. The activists' petitions, parliamentary questions, and demonstrations forced the government to justify its policy and gave rise to debate within the Swiss federal administration. Since they were highly esteemed, helped implement Switzerland's development aid policy and thus contributed to the country's humanitarian image, churches and missionary organisations had more influence on the Swiss government than other solidarity actors. By examining the interests and interactions of the different state and non-state actors involved in foreign policymaking, this study bridges diplomatic, economic, and social history.

This book is part of a growing scholarship that focuses on the Cold War in the global South. Since at least the publication of Odd Arne Westad's seminal study, The Global Cold War, the Third World has become an important research topic in Cold War historiography. ${ }^{32}$ In Africa and Asia, the Cold War overlapped and interacted with the process of decolonisation. While many newly independent nations went through internal struggles as they built their states, the Eastern and Western blocs vied with each other to win their allegiance, offering support and intervening directly to change events for their own benefit. Despite their more limited agency, the global East-West rivalry also provided Third World leaders and independence movements with opportunities to play off the superpowers against each other in order to achieve their goals. ${ }^{33}$

32 See Robert J. McMahon, "Introduction", in McMahon, The Cold War in the Third World, pp. 1-10; Westad, The Global Cold War. Consult also Mark Philip Bradley, "Decolonization, the global South, and the Cold War, 1919-1962", in Melvyn P. Leffler, Odd Arne Westad (eds.), The Cambridge History of the Cold War. Volume I: Origins, Cambridge: Cambridge University Press, 2011, pp. 464-485; Michael E. Latham, "The Cold War in the Third World, 1963-1975" in Melvyn P. Leffler, Odd Arne Westad (eds.), The Cambridge History of the Cold War. Volume II: Crises and Détente, Cambridge: Cambridge University Press, 2011, pp. 258-280, and the corresponding bibliographic essays.

33 See notably Bradley, "Decolonization, the global South, and the Cold War"; Byrne, "Africa's Cold War". Particularly interesting for the agency of African actors is Matthew Connelly, 
Many Cold War crises and all the 'hot wars' of the period took place in the global South. From the late 196os, in particular, when the policy of Détente led to a decrease in tension between the superpowers and Western Europe experienced a period of relative peace and stability, despite facing an economic crisis, East-West confrontations in the global South turned increasingly violent. A significant number of these conflicts took place on the African continent, with devastating consequences for local populations. ${ }^{34}$

The armed conflicts and regime changes in Angola, Mozambique, Ethiopia, and Somalia that are at the centre of this study have been analysed in a number of recent publications. During the liberation struggles in Southern Africa that opposed, on one side, African nationalist movements in South Africa, Rhodesia, Namibia, and the Portuguese colonies and, on the other, the white minority regimes, the intersections of decolonisation and the Cold War emerged most strikingly. As the Portuguese, Rhodesian, and South African governments refused to grant, respectively, independence to their colonies and equal rights to their African populations, liberation movements found willing allies in the Eastern bloc. For many Western governments, the fiercely anti-Communist white minority regimes represented a bulwark against Soviet and Chinese influence on the continent, which resulted in a broad tolerance, although to varying degrees, of their racist policies. ${ }^{35}$ During the late independence wars in Angola and Mozambique, African liberation movements received political and military support from the UssR, the People's Republic of China (PRC)

"Rethinking the Cold War and Decolonization. The Grand Strategy of the Algerian War for Independence", Journal of Middle East Studies 33:2 (2001), pp. 221-245. The competition for the Third World was also played out between the USSR and the PRC, and between the US and the PRC: Gregg A. Brazinsky, Winning the Third World. Sino-American Rivalry during the Cold War, Chapel Hill: The University of North Carolina Press, 2017; Jeremy Friedman, Shadow Cold War. The Sino-Soviet Competition for the Third World, Chapel Hill: The University of North Carolina Press, 2015.

34 Byrne, "Africa's Cold War".

35 For a good introduction of these dynamics, see Sue Onslow, "The Cold War in Southern Africa. White Power, Black Nationalism and External Interventions", in Sue Onslow (ed.), Cold War in Southern Africa. White Power, Black Liberation, London: Routledge, 2009, pp. 9-34. With a focus on South Africa, see Gareth Evans, "The Great Simplifier: The Cold War and South Africa, 1948-1994", in Alan P. Dobson (ed.), Deconstructing and Reconstructing the Cold War, Aldershot: Ashgate, 1999. US tolerance towards Apartheid South Africa has notably been analysed by Thomas Borstelmann, Apartheid's Reluctant Uncle. The United States and Southern Africa in the Early Cold War, New York: Oxford University Press, 1993; Alex Thomson, U.S. Foreign Policy Towards Apartheid South Africa, 1948-1994. Conflict of Interests, New York: Palgrave Macmillan, 2008. For the dynamics between US foreign policy and domestic racism, see Thomas Borstelmann, The Cold War and the Color Line. American Race Relations in the Global Arena, Cambridge, MA: Harvard University Press, 2001. 
and other members of the Eastern bloc, as well as from the newly decolonised states of Africa and Asia. Although some governments and an important transnational solidarity movement in Western Europe also granted humanitarian aid to these movements, most Western states stood behind the authoritarian Portuguese regime that was a member of NATO. From the late 196os onwards, Western support for the three white minority regimes in Southern Africa was increasingly criticised by Afro-Asian governments that insisted the West adhere to its verbal commitment to the principle of self-determination. ${ }^{36}$

In 1974, a military coup d'état that was supported by large parts of the population toppled the Portuguese government and initiated the process of decolonisation. Mozambique experienced a relatively peaceful transition of power to a Marxist-inspired government. In Angola, however, rivalries between three competing liberation movements that were backed by various external powers escalated into an open, internationalised war. With the aid of a Cuban expeditionary force, the Movimento Popular de Libertação de Angola (Popular Movement for the Liberation of Angola, MPLA) repelled a South African invasion to win the Angolan $\operatorname{War}^{37}$ in early 1976, subsequently cementing its

$3^{6}$ On Soviet support to the Southern African liberation movements, see notably Roger E. Kanet, "The Superpower Quest for Empire: The Cold War and Soviet Support for 'Wars of National Liberation', Cold War History 6:3 (2006), pp. 331-352; Vladimir Shubin, “Unsung Heroes: The Soviet Military and the Liberation of Southern Africa", Cold War History 7:2 (2007), pp. 251-262; Vladimir Shubin, The Hot 'Cold War'. The UssR in Southern Africa, London: Pluto Press, 2008; Natalia Telepneva, Our Sacred Duty: The Soviet Union, the Liberation Movements in the Portuguese Colonies, and the Cold War, 1961-1975, PhD thesis, Open Access, The London School of Economics and Political Science, 2014. See also Maxim Matusevich (ed.), Africa in Russia, Russia in Africa. Three Centuries of Encounters, Trenton: Africa World Press, 2007; Christopher Andrew, Vasili Mitrokhin, The World Was Going Our Way. The KGB and the Battle for the Third World, New York: Basic Books, 2005. On China, see Steven F. Jackson, "China's Third World Foreign Policy: The Case of Angola and Mozambique, 1961-93", The China Quarterly 142 (1995), pp. 388-422. For the US, see Witney W. Schneidman, Engaging Africa. Washington and the Fall of Portugal's Colonial Empire, Dallas: University Press of America, 2004. See also the contributions in a recent special issue: Aurora Almada e Santos, Bernardo Capanga André, Corrado Tornimbeni, Iolanda Vasile (eds.), Afriche e Orienti. International Solidarities and the Liberation of the Portuguese Colonies 19:3 (2017).

37 I use the term Angolan War for the conflict in 1975-1976 that was shaped by the South African and Cuban interventions in order to distinguish it from the independence war against the Portuguese regime between 1961 and 1974 and the civil war between the Movimento Popular de Libertação de Angola (Popular Movement for the Liberation of Angola, M PLA) and the União Nacional para a Independência Total de Angola (National Union for the Total Liberation of Angola, UNITA) after the South African retreat in 1976. 
alliance with the USSR. ${ }^{38}$ Like the liberation movements that came into power in Angola and Mozambique, the military regimes that took over in Somalia in 1969 and Ethiopia in 1974 adopted an orthodox Communist rhetoric in order to strengthen their alliance with the USSR. ${ }^{39}$ While there is not much literature on the Somali coup d'état, the Ethiopian Revolution has been analysed in some detail. 40

The Ogaden War between Ethiopia and Somalia in 1977-1978 was the only conventional conflict between two African states during the Cold War. Desperate for increased external support for its ongoing invasion of the Ogaden region in south-eastern Ethiopia-an area whose possession had been a contentious issue for the two neighbouring states since Somalia's independence in 1960- the Somali government renounced its friendship treaty with the USSR in November 1977. Yet, as the Carter administration refused to intervene in a war of aggression, and the USSR and Cuba organised a massive military operation in aid of Ethiopia, the Somali troops were forced to withdraw in March 1978. The recent historiography of the Ogaden War has focused mainly on the role of the superpowers and the conflict's negative impact on East-West relations. ${ }^{41}$

38 In addition to the titles above, see Piero Gleijeses, Conflicting Missions. Havana, Washington, and Africa, 1959-1976, Chapel Hill: University of North Carolina Press, 2002; Piero Gleijeses, Visions of Freedom. Havana, Pretoria, and the Struggle for Southern Africa, 1976-1991, Chapel Hill: The University of North Carolina Press, 2013; Edward George, The Cuban Intervention in Angola, 1965-1991. From Che Guevara to Cuito Canavale, London: Cass, 2005; Jamie Miller, An African Volk. The Apartheid Regime and its Search for Survival, New York: Oxford University Press, 2016; Jamie Miller, "Yes, Minister. Reassessing South Africa's Intervention in the Angolan Civil War, 1975-1976", Journal of Cold War Studies 15:3 (2013), pp. 4-33; Westad, The Global Cold War, pp. 218-241; Geraint Hughes, "Soldiers of Misfortune: The Angolan War, the British Mercenary Intervention, and UK Policy towards Southern Africa, 1975-6", The International History Review 36:3 (2014), pp. 493-512. For an African perspective, see John A. Marcum, The Angolan Revolution. Volume II: Exile Politics and Guerrilla Warfare (1962-1976), Cambridge, MA: MIT Press, 1978.

39 Byrne, "Africa's Cold War", pp. 110-111.

40 For Somalia, see Gary D. Payton, "The Somali Coup of 1969: The Case for Soviet Complicity", The Journal of Modern African Studies 18:3 (1980), pp. 493-5o8; Robert G. Patman, The Soviet Union in the Horn of Africa. The Diplomacy of Intervention and Disengagement, Cambridge: Cambridge University Press, 2009 (1990); Radoslav A. Yordanov, The Soviet Union and the Horn of Africa during the Cold War. Between Ideology and Pragmatism, Lanham: Lexington Books, 2016. The Ethiopian Revolution has notably been analysed by Ethiopian scholars Andargachew Tiruneh, The Ethiopian Revolution 1974-1987. A Transformation from an Aristocratic to a Totalitarian Autocracy, Cambridge: Cambridge University Press, 1993; Gebru Tareke, The Ethiopian Revolution. War in the Horn of Africa, New Haven: Yale University Press, 2009.

41 On the UssR, see Patman, The Soviet Union in the Horn of Africa; Westad, The Global Cold War, pp. 250-287; Yordanov, The Soviet Union and the Horn of Africa. On the role of the 
Although it concentrates primarily on the Carter administration's policy in the Horn of Africa, historian Nancy Mitchell's detailed analysis also highlights the important role of Western European and Arab states. ${ }^{42}$ Gebru Tareke provides a useful military history of the conflict from an Ethiopian point of view. ${ }^{43}$

With the notable exception of Cuba, which played a pivotal role during the Angolan War, scholars have paid little attention to the role of small actors during the Cold War in sub-Saharan Africa in the late 196os and 1970s. Individual studies focus on support from North European governments and civil society for national liberation in Southern Africa, ${ }^{44}$ the German Democratic Republic (GDR)'s relations with the Soviet-allied regimes in Angola, Mozambique, and Ethiopia, ${ }^{45}$ and neutral Ireland's role in Africa. ${ }^{46}$ By exploring Switzerland's opportunities to influence the situation on the ground, notably through mediation, arms sales, diplomatic recognition, and humanitarian aid, this book will contribute to filling this gap.

The existing literature on Switzerland's role during the crises and regime changes in Angola, Mozambique, Ethiopia, and Somalia is sparse. It consists mainly of unpublished masters' theses of varying quality that analyse specific aspects of Swiss involvement in these four states. Authors have focused on the

Carter administration during the Ogaden War, see Donna R. Jackson, Jimmy Carter and the Horn of Africa. Cold War Policy in Ethiopia and Somalia, Jefferson, NC: McFarland, 2007; Donna R. Jackson, "The Carter Administration and Somalia", Diplomatic History 31:4 (2007), pp. 703-721; Donna R. Jackson, "The Ogaden War and the Demise of Détente", The Annals of the American Academy of Political and Social Science 632:1 (2010), pp. 26-40; Louise Woodroofe, 'Buried in the Sands of the Ogaden'. The United States, the Horn of Africa, and the Demise of Détente, Kent, Ohio: The Kent State University Press, 2013.

Nancy Mitchell, Jimmy Carter in Africa. Race and the Cold War, Washington DC: Woodrow Wilson Center Press, 2016.

43 Gebru Tareke, The Ethiopian Revolution; Gebru Tareke, "The Ethiopia-Domalia War of 1977 Revisited", The International Journal of African Historical Studies, 33:3 (2000), pp. 635-667.

44 See Tore Linné Eriksen (ed.), Norway and National Liberation in Southern Africa, Stockholm: Nordiska Afrikainstitutet, 2000; Christopher Munthe Morgenstierne, Denmark and National Liberation in Southern Africa. A Flexible Response, Uppsala: Nordiska Afrikainstitutet, 2003; Sellström, Sweden and National Liberation in Southern Africa. Volume I: Formation of a Popular Opinion; Sellström, Sweden and National Liberation in Southern Africa. Volume II: Solidarity and Assistance; Iina Soiri, Pekka Peltola, Finland and National Liberation in Southern Africa, Stockholm: Nordiska Afrikainstitutet, 1999.

45 Sara Lorenzini, "East-South Relations in the 1970s and the GDR Involvement in Africa: Between Bloc Loyalty and Self-interest", in Max Guderzo, Bruna Bagnato (eds.), The Globalization of the Cold War: Diplomacy and Local Confrontation, 1975-1985, London: Routledge, 2010, pp. 104-115; Klaus Storkmann, Geheime Solidarität: Militärbeziehungen und Militärhilfen der DDR in die 'Dritte Welt', Berlin: Ch. Links Verlag, 2012, pp. 243-384.

46 Kevin O'Sullivan, Ireland, Africa and the End of Empire. Small State Identity in the Cold War 1955-1975, Manchester: Manchester University Press, 2012. 
activities of the Swiss Mission in Mozambique, ${ }^{47}$ Swiss groups and individuals that expressed their solidarity with the independence struggles in Portuguese Africa, ${ }^{48}$ Swiss economic activities in colonial Angola and Mozambique, ${ }^{49}$ Angolan refugees in Switzerland, ${ }^{50}$ the view of the Swiss embassy in Addis Ababa on the Ethiopian Revolution of $1974,{ }^{51}$ and the controversy surrounding the Ethiopian Emperor's Swiss bank accounts in $1974-1975 .{ }^{52}$ The present book thus sheds light on the neglected field of Swiss bilateral relations with these four African states. It thereby also contributes to the growing but still small body of literature on Swiss political, economic, and humanitarian relations with sub-Saharan African countries during decolonisation. ${ }^{53}$ In recent years,

47 See notably Sérgio Inácio Chichava, "Unlike the Other Whites? The Swiss in Mozambique under Colonialism" in Eric Morier-Genoud, Michel Cahen (eds.), Imperial Migrations. Colonial Communities and Diaspora in the Portuguese World, Houndsmills: Palgrave Macmillan, 2012, pp. 149-167; Teresa Cruz e Silva, Protestant Churches and the Formation of Political Consciousness in Southern Mozambique (1930-1974), Basel: P. Schlettwein Publishing, 2001; Patrick Harries, Butterflies \& Barbarians. Swiss Missionaries \& Systems of Knowledge in South-East Africa, Oxford: James Currey, 2007; Caroline Jeannerat, Eric Morier-Genoud, Didier Péclard, Embroiled. Swiss Churches, South Africa and Apartheid, Münster: Lit-Verlag, 2011; Charles Rohrbasser, L'œuvre sociale de la Mission Suisse au Mozambique, unpublished Master thesis, University of Lausanne, 1991.

48 See notably Rahel Fischer, 'Die Solidarität in den Strukturen'. Entwicklungspolitische Konzepte, Aktionen und Lebenswelten der Arbeitsgruppe Dritte Welt Bern, 1968-1976, unpublished Master thesis, University of Bern, 2007; several contributions in Schaufelbuehl, 1968-1978; Andrea Steinemann, Medic'Angola und Komitee Südliches Afrika. Über das Entstehen, die Veränderung und das Verschwinden einer Schweizer Solidaritätsgruppe in den 197oer Jahren, unpublished Master thesis, University of Zurich, 2014.

49 Chichava, “Unlike the Other Whites?"; Adolphe Linder, Die Schweizer in Mosambik 1721199o, Capetown: Rondebosch, 1998; Tiago Ribeiro, L'attitude de la Confédération suisse visà-vis des mouvements indépendantistes angolais (1960-1975), unpublished Master thesis, University of Lausanne, 2011; Laure Schwager, La Suisse et ses liens politiques et économiques avec l'Angola pendant la Guerre froide (1974-1979), unpublished Master thesis, University of Lausanne, 2014.

$50 \quad$ Eliane Kurmann, 'Affaires angolaises'. Die angolanischen Studenten in der Schweiz während dem Unabhängigkeitskampf 1961-1975, unpublished Master thesis, University of Fribourg, 2008.

$5^{1} \quad$ Christian Scherer, Durch die tiefsten Tiefen des Wellentals. Die äthiopische Revolution in den Politischen Berichten der Schweizerischen Botschaft in Addis Abeba, 1970-1975, unpublished Master thesis, University of Bern, 2009.

$5^{2} \quad$ Sakina el Ammari, Les autorités politiques suisses face aux réclamations d'avoirs illicites deposes dans les banques suisses: le cas du 'blood money' de l'empereur éthiopien Haïlé Sélassié (1974), de Ferdinand Marcos aux Philippines (1986) et de Jean-Claude Duvalier en Haïti (1986), unpublished Master thesis, University of Lausanne, 2017.

53 Marisa Birri, "Der Kalte Krieg war in Afrika ein Heisser. Die Schweiz und der Kongokonflikt 196o-1963", in Bott, Schaufelbuehl, Zala, Die internationale Schweiz in der Zeit des Kalten Krieges, pp. 65-79; Philippe Boeglin, La coopération entre la Suisse et le Burkina 
an increasing number of scholars have started to analyse the unequal political, economic, financial, religious, social, and scientific relations of Switzerland, a small, export-oriented European state without colonies, and/or its citizens, with countries and actors in the Third World, both during and after colonialism. While some authors, mostly from the viewpoint of economic history, have sought to determine the existence of a specific form of 'Swiss imperialism', others, influenced by postcolonial studies, have looked at colonial discourses in Switzerland and studied forms of 'colonialism without colonies'.54 Thanks to

Faso. Continuité en régime révolutionnaire (1983-1987), unpublished Master thesis, University of Fribourg, 2010; Sandra Bott, Thomas David, Claude Lützelschwab, Janick Marina Schaufelbuehl (eds.), Suisse-Afrique (18e-2oe siècles). De la traite des Noirs à la fin du régime d'apartheid, Münster: LIT Verlag, 2005; Alioune Dieng, A l'ombre de la France. Les relations entre le Sénégal et la Suisse au lendemain de l'indépendance (1960-1964), unpublished Master thesis, University of Neuchâtel, 20o8; Alioune Dieng, La Suisse et l'Afrique aux lendemains des indépendances: le cas de la Côte d'Ivoire, unpublished Master thesis, The Graduate Institute, Geneva, 2010; Ursin Hofmann, La politique d'aide au développement suisse pour le Tiers-monde. La relation entre la Confédération helvétique et la Banque africaine de développement entre intérêts propres et altruisme (1964-1975), unpublished Master thesis, University of Lausanne, 2011; Mathieu Humbert, "Une défense discrète et flexible des intérêts économiques suisses. Les cas du Ghana et du Congo au début de leur indépendance", Relations internationales 163:3 (2015), pp. 63-79; Lyonel Kaufmann, "Guillaume Tell au Congo. L'expansion suisse au Congo belge (1930-196o)", Les Annuelles 5 (1994), pp. 43-94; Lukas Meier, Swiss Science, African Decolonization and the Rise of Global Health, 1940-2010, Basel: Schwabe, 2014; Steve Page, La Suisse et le Ghana de Nkrumah: une présence économique et diplomatique à l'épreuve de la décolonisation (1950-1970), unpublished Master thesis, University of Fribourg, 2006; Steve Page, Le Nigeria et la Suisse, des affaires d'indépendance. Commerce, diplomatie et coopération 1930-1980, Bern: Peter Lang, 2016; Pascal Schmid, Medicine, Faith and Politics in Agogo. A History of Health Care Delivery in Rural Ghana, ca. 1925 to 1980, Zürich: LIT Verlag, 2018; Jérôme Schuwey, La Suisse et la Guinée de Sékou Touré. Les enjeux de la Coopération technique au lendemain de l'indépendance (1958-1974), unpublished Master thesis, University of Lausanne, 2011; Lukas Zürcher, “So fanden wir auf der Karte diesen kleinen Staat': Globale Positionierung und lokale Entwicklungsfantasien der Schweiz in Rwanda in den 196oer Jahren", in Hubertus Büschel, Daniel Speich (eds.), Entwicklungswelten. Globalgeschichte der Entwicklungszusammenarbeit, Frankfurt: Campus Verlag, 2009, pp. 275-309; Lukas Zürcher, Die Schweiz in Ruanda. Mission, Entwicklungshilfe und Nationale Selbstbestätigung (1900-1975), Zurich: Chronos, 2014.

54 For historiographical overviews, see notably Thomas David, Bouda Etemad, "Introduction", Les Annuelles 5 (1994), pp. 7-17; Thomas David, Bouda Etemad, "Un impérialisme suisse? Introduction", Traverse 5 (1998), pp. 7-16; Bouda Etemad, Mathieu Humbert, "La Suisse est-elle soluble dans sa 'postcolonialité'?" Schweizerische Zeitschrift für Geschichte 64:2 (2014), pp. 279-291; Patricia Purtschert, Harald Fischer-Tiné, "Introduction. The End of Innocence: Debating Colonialism in Switzerland”, in Patricia Purtschert, Harald Fischer-Tiné (eds.), Colonial Switzerland. Rethinking Colonialism from the Margins, Basingstoke: Palgrave Macmillan, 2015, pp. 1-25; Patricia Purtschert, Barbara Lüthi, Francesca 
a national research programme, mandated by the Swiss government in 2000 following public and parliamentary pressure concerning the issue of Switzerland's responsibility for the perpetuation of racial discrimination in South Africa, Swiss relations with the Apartheid regime have received particular attention. ${ }^{55}$ Although more research is still needed on Switzerland's relations with the Rhodesian settler regime that unilaterally declared its independence from the UK in 1965 , there are indications that firms domiciled in Switzerland played a central role in the evasion of the economic sanctions imposed on the country by the UN. ${ }^{56}$ Moving away from a purely bilateral view of such relations, this book shows that these economic links and the Swiss government's non-committal stance on racial discrimination loomed large over its relations with independent Afro-Asian governments in the 196os and 1970s and imperilled its image in the Third World.

The strategies adopted by Swiss foreign policymakers to deal with this contributed to and were influenced by a general reappraisal of Switzerland's foreign policy that started in the late 196os. This was prompted by a growing awareness that, in an international context marked by superpower Détente and the increasingly confident stance of newly decolonised states in the Third World, strict adherence to Switzerland's conception of neutrality might lead to the country's isolation. The Swiss government therefore decided to adopt a more active and outward-looking position to defend its interests in a changing global context. Research has focused, in particular, on Bern's decision to take

Falk, "Eine Bestandesaufnahme der postkolonialen Schweiz", in Patricia Purtschert, Barbara Lüthi, Francesca Falk (eds.), Postkoloniale Schweiz. Formen und Folgen eines Kolonialismus ohne Kolonien, Bielefeld: Transcript, 2012, pp. 13-63.

In 2000, the Swiss government charged the Swiss National Science Foundation (SNF) with carrying out a national research programme to study Switzerland's relations with the Apartheid regime. This project was not only hampered by the destruction of a number of relevant files but also by the government's April 2003 decision to block access to documents dated after 1960 in the SFA. For background of research programme $42+$ and its political context, see its final report: Georg Kreis, Die Schweiz und Südafrika 1948-1994. Schlussbericht des im Auftrag des Bundesrates durchgeführten NFP 42+, Bern: Haupt, 2005, pp. 21-73. Other studies include Sandra Bott, Sébastien Guex, Bouda Etemad, Les relations économiques entre la Suisse et l'Afrique du Sud durant l'apartheid (1945-1990), Lausanne: Antipodes, 2005; Jeannerat, Morier-Genoud, Péclard, Embroiled.

56 On Swiss-Rhodesian economic relations, see Franziska Brunner, Die Beziehungen Schweiz-UNO im Kontext des Rhodesienkonflikts. Eine Neubewertung der multilateralen Zusammenarbeit, unpublished Master thesis, University of Bern, 2011; Jürg Martin Gabriel, "Switzerland and Economic Sanctions: The Dilemma of a Neutral", in Milivojevic, Maurer, Swiss Neutrality and Security, pp. 232-245; Rudolf Letsch, Rhodesien, die Vereinten Nationen und die Schweiz. Konzepte und Inkonsistenzen der Rhodesienpolitik, Herisau: Druck Schläpfer + Co. AG, 1983; Ross, Neutrality and International Sanctions. 
steps towards joining the UN (which was rejected in a popular vote in 1986 ), ${ }^{57}$ its active participation in the multilateral negotiations at the Conference on Security and Co-operation in Europe (CSCE) between 1972 and 1975, ${ }^{58}$ its security policy, ${ }^{59}$ its policy on human rights, ${ }^{60}$ and its participation in international cooperation on counterterrorism. ${ }^{61}$

To date, Thomas Fischer's 2004 study remains the most detailed account of the turn towards a more active Swiss foreign policy in the late 196os and the return to a foreign policy approach based on a restrictive and selective interpretation of neutrality in the late 1970s and 1980s. Although his book focuses on the Northern hemisphere, like most works analysing this reorientation, Fischer underlines that the Third World played an integral part in the reconsideration of Swiss foreign policy. Relying exclusively on Swiss government sources and the private papers of foreign policymakers, he shows that, in the Third World, the Swiss authorities faced increasingly self-confident governments that demanded a greater say in international political and economic relations. Consequently, the Swiss government realised that, in order to protect its international standing, it needed to show more consideration to and intensify its relations with the recently decolonised countries in the global South. ${ }^{62}$ This point was subsequently developed in a number of recent works. ${ }^{63}$ The pre-

57 See Sandra Bott, Janick Marina Schaufelbuehl, "Switzerland and Détente: A Revised Foreign Policy Characterized by Distrust", in Martin Klimke, Reinhild Kreis, Christian F. Ostermann (eds.), Trust, but Verify. The Politics of Uncertainty and the Transformation of the Cold War Order, 1969-1991, Washington, DC: Woodrow Wilson Center Press, 2016, pp. 259-278; Thomas Fischer, Die Grenzen der Neutralität. Schweizerisches KSZE-Engagement und gescheiterte UNO-Beitrittspolitik im Kalten Krieg, 1969-1986, Zürich: Chronos, 2004.

$5^{8} \quad$ Fischer, Die Grenzen der Neutralität; Christoph Breitenmoser, Sicherheit für Europa. Die KSZE-Politik der Schweiz bis zur Unterzeichnung der Helsinki-Schlussakte zwischen Skepsis und aktivem Engagement, Zürich: ETH, 1996; Philip Rosin, Die Schweiz im KSZE-Prozess 1972-1983. Einfluss durch Neutralität, München: Oldenbourg Verlag, 2014. On the role of the European neutral countries, see Thomas Fischer, Neutral Power in the cscE. The $N+N$ States and the Making of the Helsinki Accords 1975, Baden-Baden: Nomos, 2009; Victor-Yves Ghebali, La diplomatie de la détente: La cscE, d'Helsinki à Vienne (1973-1989), Bruxelles: Emile Bruylant, 1989 .

59 Christoph Breitenmoser, Strategie ohne Aussenpolitik. Zur Entwicklung der schweizerischen Sicherheitspolitik im Kalten Krieg, Bern: Peter Lang, 2002.

6o Jon A. Fanzun, Die Grenzen der Solidarität:schweizerische Menschenrechtspolitik im Kalten Krieg, Zürich: NZZ, 2005.

61 Aviva Guttmann, The Origins of International Counterterrorism. Switzerland at the Forefront of Crisis Negotiations, Multilateral Diplomacy, and Intelligence Cooperation (19691977), Leiden: Brill, 2018.

62 Fischer, Die Grenzen der Neutralität.

63 See notably Magnus Meister, Swiss Economic and Political Relations with Israel, Egypt and Syria During the Arab-Israeli Conflicts (1967-1983), unpublished PhD thesis, University of 
sent study thus addresses a research deficit. Its key benefits are the multiple points of view and levels of analysis. It evaluates not only the impact of Swiss non-state actors on the formation of foreign policy but also the role and influence of Western governments, thereby placing Swiss foreign policy in both an international and transnational context. ${ }^{64}$

The extensive multi-archival research undertaken for this study reflects this approach. This book is based on a large and diverse body of primary documents from public and private archives in Switzerland, the US, the UK, France, and Portugal. The consultation of African archives was, however, outside of the scope of this book, for linguistic reasons as well as difficulties of access. Some printed African sources and secondary literature based on African archivessome of it written by African scholars - balance the predominantly Swiss and Western view of events in Southern Africa and the Horn of Africa. The bulk of archival research was conducted at the Swiss Federal Archives (SFA) in Bern. Research focused on the documents of different divisions within the Federal Political Department (FPD ) — Switzerland's foreign ministry: the Directorate of Political Affairs (DPA), the department's chief division and coordinating unit of Swiss foreign policy responsible for its operational aspects; the Directorate for International Organisations (DIO); the Service for Technical Cooperation (STC); the Political Secretariat; and the Swiss embassies in sub-Saharan Africa. The archives of the Federal Department of Economic Affairs' (FDEA) Trade Division were also consulted, as well as selected files of the Federal Department of Finance (FDF) and the Federal Military Department (FMD).

The vast array of different documents from the Swiss federal administration was complemented by papers from the archives of a number of economic, missionary, activist, and humanitarian groups and organisations in Switzerland. The minutes of governing body meetings of leading economic and financial associations were consulted, such as the Swiss Federation of Commerce and Industry (Vorort) at the Archiv für Zeitgeschichte (Archives for Contemporary History, AfZ) in Zurich and the Swiss Bankers Association (sBA) in Basel, as well as the Swiss National Bank (SNB) in Zurich. Archival research was also

Lausanne, 2019; Schaufelbuehl, Wyss, Bott, "Choosing Sides in the Global Cold War"; and the contributions in a special issue on Switzerland's role during the Cold War in the Third World. For an overview, see Sandra Bott, Jussi M. Hanhimäki, Janick Marina Schaufelbuehl, Marco Wyss, "Introduction. Le role international de la Suisse dans la Guerre froide globale: un équilibre précaire", Relations internationales 163:3 (2015), pp. 3-13.

64 Pierre Eichenberger, Thomas David, Lea Haller, Matthieu Leimgruber, Bernhard C. Schär, Christa Wirth, "Beyond Switzerland. Reframing the Swiss Historical Narrative in Light of Transnational History", Traverse 24:1 (2017), pp. 137-152. 
conducted at the company archives of two leading Swiss export firms whose archives are open to researchers: electro-technical company Brown, Boveri \& Cie (ввС, today Авв) and pharmaceutical group Ciba-Geigy (today Novartis). These firms represent the two most important Swiss export sectors to the African continent: chemicals and machines. To cover the perspective of other non-state actors, the archives of Swiss Maoist solidarity group Medic'Angola at the Basler Afrika Bibliographien. Namibia Resource Centre \& Southern Africa Library (ВАВ) and the Département missionnaire des églises protestantes de Suisse romande (the mission wing of the Protestant churches of French-speaking Switzerland, DM) in Lausanne provided fascinating insights. Finally, research was conducted at the ICRC archives in Geneva.

In order to situate Swiss foreign policy on sub-Saharan Africa in the broader context of the global Cold War, additional research was carried out at the foreign ministry archives of Western states that played an important role during the conflicts analysed in this book: the US and the three colonial powers, Portugal, France, and the UK. The documents gathered there shed new light on the major Western powers' view of Switzerland's foreign policy in the Third World during Détente. Archival research was complemented by the analysis of published sources and online collections, such as the diplomatic documents of Switzerland and the US, contemporary official publications, annual reports, and press reports.

Rather than following a strictly chronological approach, this study is divided into three thematic parts. They focus, respectively, on Switzerland's foreign policy during the late independence wars in Angola and Mozambique (19671974), the radical regime changes that occurred in Somalia, Ethiopia, Mozambique, and Angola (1969-1979), and Swiss actors' roles in and reactions to the wars in Angola and the Ogaden (1975-1979). Although the time frames do to some extent overlap, this structure allows a more in-depth analysis of the specific problems faced by Swiss foreign policymakers with regard to sub-Saharan Africa. A first, introductory chapter sketches Switzerland's foreign policy during decolonisation in sub-Saharan Africa from the late 1950s to the late 197os. It also situates its political, economic, and humanitarian interests in the four selected African states in this general context.

The analysis begins in 1967, when African governments, liberation movements, and a heterogeneous Swiss solidarity movement started to single out and condemn the Swiss government's cordial relations with the white minority regimes in South Africa, Rhodesia, and the Portuguese colonies, and the role of Swiss firms and banks in stabilising those regimes. Part 1 shows how the Swiss government dealt with this criticism during the late independence wars 
in Angola and Mozambique and how its strategy compared to that of other Western and neutral states. Chapter 2 focuses on criticism issued in the international arena. It argues that the Swiss government refused to take a stand on Portuguese colonialism out of fear that this would set a precedent for its relations with the Apartheid regime. Nevertheless, it undertook some limited efforts to show Swiss goodwill towards the African populations in Southern Africa through the supposedly non-political instrument of humanitarian aid. Chapter 3 opens the floor to the large and diverse Swiss movement for solidarity with the liberation struggles in Portuguese Africa. It demonstrates that, as a result of such protest, some members of the Swiss federal administration started to advocate a new foreign policy approach to Africa, which paid more attention to independent African governments. Although they remained in the minority, the Swiss government had, by 1974, come under considerable political pressure to improve its image, and that of its neutrality, on the African continent.

The three chapters in part 2 focus on the political transformations in Angola, Mozambique, Ethiopia, and Somalia that brought Marxist-inspired governments to power and were accompanied, to various extents, by anti-Western rhetoric and the nationalisation of foreign investments. Concentrating on the Horn of Africa, chapter 4 shows that the 1969 coup d'état in Somalia was met with little interest in Bern, as Swiss political, economic, or missionary interests were almost non-existent and the Socialist rhetoric of the new government was not considered unusual for an African state. The Ethiopian Revolution of 1974, however, was accompanied by virulent attacks against Swiss banks for harbouring the assets of the deposed Ethiopian Emperor. The Swiss government subsequently adopted a strategy of problem management and waited out the crisis. In chapter 5 , the narrative returns to Southern Africa, where the Portuguese Revolution of April 1974 heralded the decolonisation of Angola and Mozambique; Swiss foreign policymakers perceived this as an opportunity. The chapter demonstrates that in 1974-1975, the need to improve Switzerland's image in the Third World, due to its former association with the colonial power, spurred the government's efforts to establish cordial links with the future rulers of Angola and Mozambique by granting humanitarian aid and establishing diplomatic relations. As detailed in chapter 6, Bern was confronted with some difficulties in Mozambique. The new government that came into power in June 1975 prioritised political relations with those states that had supported its independence struggle, notably the Eastern bloc and neutral Sweden. The nationalisation of foreign property and the state's control of the import sector tested Swiss settlers and export firms. The conclusion of 
an economic and development cooperation agreement in 1979, however, put an end to the bilateral difficulties of the post-independence years. Part 2 shows that the Swiss government's response to the regime changes was largely pragmatic and influenced by the wish to maintain or increase Switzerland's political and economic presence and improve its image, irrespective of the new rulers' ideological orientations. The need to win favour with African and Third World states was more important than political and ideological ties to the US. During the political transformations in 1974 and 1975, Swiss policy decisions in sub-Saharan Africa were coordinated, in the first place, with the neutral governments of Sweden and Austria, and in the second place, with the capitals of the EEC. The increased importance of Western Europe was accompanied by signs of a growing Swiss disenchantment with the Ford administration's Africa policy and its ability to influence events on the African continent.

Part 3 turns to Swiss foreign policymakers' and humanitarian actors' roles in and perception of the wars in Angola (chapter 7) and the Ogaden (chapter 8), as well as the influence of these conflicts on Switzerland's foreign policy in Africa. When Angola became independent in November 1975 in the middle of an internationalised war, the Swiss government was confronted with the delicate issue of diplomatic recognition of the new state. Chapter 7 argues that the recognition of the Soviet-allied MPLA government by African states in February 1976, towards the end of the conflict, was decisive in the decision by Switzerland and other neutral and Western European states to follow suit, even though the Ford administration opposed this. Thanks to its considerable support for the ICRC relief mission during the Angolan War, the Swiss government quickly established cordial bilateral relations with the MPLA regime. In Bern, however, the Cuban military intervention in Angola—seen by many observers as a proxy force of the USSR - raised fears of further Soviet expansion in Southern Africa. As chapter 8 demonstrates, the Swiss government adopted a very passive attitude during the Ogaden War of 1977-1978. In the wake of the Angolan War, Swiss foreign policymakers perceived the conflict in the Horn to be further proof of the Soviet Union's expansionist designs and the US government's decreasing influence on the African continent. Although they felt the need to participate in the containment of Soviet influence on the African continent, their close relations with Apartheid South Africa restricted policy options. Even Bern's limited efforts to strengthen political and diplomatic ties with Africa met with domestic resistance. As global East-West tensions grew and the challenges to Switzerland's neutrality policy that had been issued by Afro-Asian governments and Swiss non-state actors lost momentum, the drive towards a more Third World oriented foreign policy stalled. The controversy raised in Switzerland by Foreign Minister Pierre Aubert's 1979 visit to Western 
Africa, which reveals the great scepticism, within parliament and public opinion, of the active foreign policy proposed by the Swiss government since the late 196os, therefore closes this study.

\section{Linguistic Notes}

For expressions, as well as personal and geographical names in Amharic and Arabic, the transliterations most frequently used in English-language literature have been followed.

Ethiopians are known by their first name. They do not have permanent family names, but add their father's first name to their own personal name. ${ }^{65} \mathrm{In}$ order to minimise confusion due to the irregular application of this convention in secondary literature, this book always uses an Ethiopian person's complete name, including in references, and lists Ethiopians by their first name. An exception is made for the Ethiopian leader Mengistu Haile Mariam, who is sufficiently well-known by his personal name alone-Mengistu.

65 Bahru Zewde, A History of Modern Ethiopia, 1855-1991, Oxford: James Currey, 2nd edition 2001, p. 28 o. 